\title{
IN MEMORIAM DEL PRESBÍTERO ALBERTO VILLARROEL CARMONA
}

El profesor Pbro. Alberto Villarroel Carmona nació el 16 de junio de 1936, y fue en 1967 que se ordenó sacerdote. Estudió Derecho en nuestra Facultad e ingresó al Seminario poco después de haberse titulado como abogado. Obtuvo el Magíster en Teología en la Pontificia Universidad Católica de Chile, y posteriormente se licenció en Derecho Canónico, en la Pontificia Universidad Católica de Comillas, en Madrid, España.

Fueron varias las áreas en las cuales desplegó su talento y con enorme generosidad compartió los dones con que el Señor lo bendijo; entre ellas, fue vicario parroquial en las parroquias El Buen Pastor y Santa Elena, ambas de la Arquidiócesis de Santiago. Además, fue capellán del Ejército, con el grado de mayor, siendo reconocido por la importante labor pastoral que desarrolló en el ámbito de la asistencia religiosa a las Fuerzas Armadas, llegando a ocupar el cargo de Canciller del Obispado castrense.

Sin embargo, fue a través de su trabajo en la Facultad de Derecho de la Pontificia Universidad Católica de Chile, y en el Tribunal Nacional Eclesiástico de Apelación, que pude conocer al sacerdote, profesor, juez, y amigo que encontré en el padre Alberto, y son precisamente esos dos ámbitos del ejercicio de su ministerio a los que quisiera referirme en esta especial ocasión.

En efecto, el padre Alberto comenzó a ejercer un intenso trabajo académico en la Facultad en el año 1975, siendo designado profesor titular. Fue Director del Departamento de Derecho Canónico desde 1990 hasta el 16 de marzo de este año, cuando el Señor lo llamó a su encuentro. También fue miembro del Consejo Académico de la Facultad, entre los años 1995 y 2005. Como profesor de Derecho Canónico dictó el ramo respectivo con singular entusiasmo, cada año con renovados objetivos, producto de su curiosidad intelectual y sus profundas reflexiones acerca de la importancia del ramo en la formación de los alumnos de Derecho, que los distinguiera del resto de los estudiantes y entre los futuros abogados, como egresados de esta Facultad.

Además, participó en el Diplomado de Derecho Canónico, donde impartió temas relacionados con el Derecho Patrimonial Canónico y el Derecho Matrimonial Canónico, dos áreas donde el servicio a la Iglesia y a la sociedad exige una amplia y responsable preparación, tanto en los abogados como en el clero y los religiosos. Con esta misma orientación, el padre Alberto ofreció durante varios semestres un curso denominado "Matrimonio y Familia", como optativo de profundización, que buscaba completar la formación recibida por los estudiantes en el curso mínimo, ahondando en la Revelación, el Magisterio, la doctrina y jurisprudencia de la Iglesia sobre la familia y la institución matrimonial, y también constituía una instancia de estudio, sobre esos temas, abierta a quienes tenían la intención de colaborar con la Iglesia en el servicio que la misma presta a sus fieles a través de los Tribunales eclesiásticos. Fue precisamente esa instancia en la cual tuve la oportunidad de relacionarme con el padre Alberto por primera vez, siendo bendecida desde ese momento con innumerables muestras de su generosidad como profesor primero, jefe después, colega, y amigo siempre.

Como parte de su vasta labor como académico, el profesor Alberto Villarroel fue autor de destacadas publicaciones, entre ellas: "Libertad religiosa, signo de nuestros tiempos", "El Vicariato Castrense", "Nuevas perspectivas para la pastoral castrense"; "Constitución Apostólica Spirituali Militum Curae"; "El matrimonio desde la perspectiva canónica” y "El derecho primario de los padres en la educación de los hijos".

Asimismo, estaba trabajando en tres proyectos, a los que dedicaba mucho tiempo y esfuerzos, aun cuando su salud ya estaba muy deteriorada, pues su inagotable creatividad lo acompañó hasta el final de sus días. El primero de estos proyectos era la publicación de un "Curso de Derecho Canónico para abogados y estudiantes de Derecho”. El segundo, la edi- 
ción de un Código de Derecho Canónico, que incorpora de forma sistemática las fuentes de los cánones, las interpretaciones auténticas de la autoridad suprema de la Iglesia respecto de algunos de ellos, y la legislación complementaria dada por la Conferencia Episcopal de Chile, además de varios apéndices que incluyen también las normas relativas al Obispado castrense. Finalmente, su tercer proyecto está relacionado con un antiguo anhelo del padre Alberto, que consiste en contar con una Facultad de Derecho Canónico en Chile, y específicamente, en nuestra Universidad. Como colaboradora del padre en todos ellos, puedo dar testimonio del fervor y convicción con que emprendió cada proyecto, y eso no pudo más que inspirar mi compromiso con él para continuarlos, en carácter personal y también como miembro del Departamento de Derecho Canónico que tantos años dirigió.

Todas estas actividades eran acompañadas por sus notables cualidades de investigador, su condición de estudioso, su trabajo metódico y exhaustivo. Ello también lo revelaba como un excelente director de tesis, que no dudaba en abrir las puertas de su valiosa biblioteca personal a los alumnos a quienes dirigía, así como también a los profesores que acudíamos a él, reposando en su vasta experiencia, en busca de bibliografía específica para preparar clases, ponencias, publicaciones.

El padre Alberto siempre, y ante todo, fue sacerdote. Muchas veces, trabajando ambos en su oficina de la Facultad, bajo la presión de plazos y urgencias, me proponía hacer una pausa porque llegaba un alumno que necesitaba conversar con él algún tema personal que lo aquejaba, o porque tenía que ir a confesar, o celebrar Misa, o ir a ver a algún profesor al que notó preocupado unos minutos antes cuando se habían cruzado en los pasillos de la Facultad. Entonces todo podía esperar, porque su labor pastoral con la comunidad universitaria era objeto de su especial atención.

Finalmente, quisiera destacar también la labor de monseñor Alberto Villarroel Carmona, como vicario judicial del Tribunal $\mathrm{Na}$ - cional Eclesiástico de Apelación, que depende de la Conferencia Episcopal de Chile, y donde cumplió su oficio desde 1990 hasta el día de su muerte. La actividad judicial por él desarrollada, como vicario y como juez, fue una manifestación constante de sus conocimientos del Derecho Canónico, en sus dimensiones sustantiva y procesal, y también del criterio jurídico que emana de muchos años de estudio y experiencia, y que revela un conocimiento profundo de la naturaleza humana, de sus debilidades, ciertamente, pero también de su dignidad, en cuanto hijos de Dios, creados a su imagen y semejanza, capaces de conocerlo y de amarlo.

Nuestro querido padre Alberto se preparó para el encuentro con el Señor con la serenidad y entereza propia de quienes se saben hijos de Dios, se entregan a su voluntad, y esperan en Él confiando en su misericordia infinita. Su más valioso testimonio, probablemente, sea el que nos entregó en los primeros días del año académico, cuando ya con mucha dificultad, a causa de su deteriorada salud, perseveraba en la determinación de continuar con sus tareas académicas. Su vida fue un constante ejemplo de ministerio entendido como servicio, que generaba el respeto y la admiración de sus alumnos, de los profesores, de las personas que trabajaron junto a él en cada uno de los ámbitos que impregnó de su dedicación y cariño.

No cabe duda que con su partida, el Padre Alberto ha dejado un vacío enorme en la Facultad, así como también en la Iglesia en Chile, en un campo de tanta relevancia como es el Derecho Canónico; también ha partido el sacerdote, confesor y guía espiritual, que supo acompañarnos con su consejo y oración. Su enseñanza será siempre inspiración y su paso por nuestras vidas un regalo maravilloso del Señor.

VALERIA LÓPEZ MANZINI Profesora de Derecho Canónico de la

Facultad de Derecho de la Pontificia Universidad Católica de Chile, Patrono estable del Tribunal Interdiocesano de Santiago. 